\title{
Utilization of Some Fruits and Vegetables Pulp in Processing (Sheets' Sweets Pieces) Products.
}

\author{
Nesreen M. El-Said Ali
}

Food Technology Research Institute, Agricultural Research Center, Giza, Egypt.

\begin{abstract}
$F$ Tresh fruits have a short harvest season and are sensitive to deterioration therefore are made fruit sheets to preserve them by adding to them many additives and preservatives. They eaten as snacks or desserts and have a concentrated fruit flavor and nutritional aspects. This study making sheets' sweets pieces from (pulp, juices) of some fruits and vegetables compared to commercial sheets and blank sheets done. These made by stimulating pectin during adding lemon salt, lemon juice and a little sugar without any additives and preservatives. Results that, vitamin $C$ of golden berries sheets sample was the highest value. Total sugars of persimmon and wholly prickly pear sheets were the highest value but the other pumpkin sheets sample including control had value were less. Total antioxidants activity for the most of sheets samples are no significantly differences except persimmon sheets had low as that of control sheets. The most of sheets samples are involved of both macronutrients and micro-minerals content. The reconstitution ratio that there are significantly differences between all sheets samples compared to the control and blank sample. Panel test it indicated that there are slight significantly differences in between sheets samples compared to control and blank while the blank and samples exceed the control. The study recommend that did not use any binding materials. The results indicated that this new idea tended to direct remedy with the same components of the pulp and juice, where these products could be instead of artificial sweets.
\end{abstract}

Key words; pulp, juices (fruits and vegetables), sheets'sweets pieces.

Bulletin of the National Nutrition Institute of the Arab Republic of Egypt. December 2019 (54)78 


\section{INTRODUCTION}

Fruit leather, also called a fruit bar or a fruit slab, is a dehydrated fruit-based confectionery dietary product, which is often eaten as snack or dessert. It is chewy and flavorful, naturally low in fat and high in fibers and carbohydrates; it is also lightweight and easily stored and packed, (Lemuel et al., 2014). Consuming fruit leather is an economic and convenient valueadded substitute for natural fruits as a source for various nutritional elements. Furthermore, fruit leather has far fewer calories, less or equal than $100 \mathrm{kcals}$ per serving, (Huang and Hsieh, 2005).

Moisture is removed from the wet purees, which are usually laid on a large flat tray until the fruit puree or a prepared boiled fruit juice with additives changes into cohesive "leathery" sheets (Moyls, 1981). Fruit leathers are often considered as a health food and health food marketing images such as "pure," "sun-dried," or "rich in vitamins" are used to describe them (Vatthanakul, et al., 2010).

Fruit leathers are dehydrated fruit based products. They are tasty, chewy, dried fruit products. Fruit leathers are made by pouring pureed fruit onto a flat surface for drying. When dried, the fruit pulled from the surface and rolled. It gets the name "leather" from the fact that when the pureed fruit is dried, it is shiny and has the texture of leather. Fruit leather generally lasts quite a long time in this state and does not require refrigeration.

The popularity of the fruit leather increased significantly in the last 10 years because many view these snacks are more healthy than other confections because it is processed from fruit to which vitamins (particularly vitamin C) has been added. The advantages of making our own fruit leathers are to use less sugar and to mix fruit flavors. For the diabetic adult or child, fruit leathers made without sugar are a healthy choice for snacks or desserts. Individual fruit leathers should contain the amount of fruit allowed for the fruit exchange. Lemon juice can be to help brighten the flavor of the fruit. Also for color, lightening and can add ascorbic acid.

Drying removes the moisture from the fruit leather so that bacteria, yeasts and molds cannot grow and spoil the fruit leather. It also slows down the action of enzymes, but does not inactivate them. Because drying removes moisture, the food becomes smaller and lighter in 
weight. Care should be taken not to keep any plastic wrap from touching the sides of the dehydrator, (Rozina Naz, 2012). Citric acid produced a similar acid taste to the traditional apricot sheets. The sheets were highly acceptable to a small panel and have potential for manufacture as a possible alternative to apricot sheets (Kamar- Eddin).

The technique could also be used for preservation in many other arid parts of the world where prickly pears grow, (Ewaidah and Hassan, 1992). Most fruit leathers are prepared by mixing fruit puree and other additives like sugar, pectin, acid, glucose syrup, color, and potassium meta-bisulphite and then dehydrating them under specific conditions, (Lemuel et al., 2014).

Thus, the aim of this study is to investigate the possibility of producing new products, which are eaten as snacks or desserts. Sheet's sweets pieces will be made from fruits and vegetables (pulp/juices).These products will be free of any additives and preservatives such as met-bisulfate (sulfur salts) or bicarbonate sodium, carboxy methylcellulose, starch and golden syrup.

\section{MATERIALS \& METHODS}

\section{1-Materials}

Golden berry (physalis peruviana), Apricot (Prunus Armeniaca $\underline{L}$ ), Persimmon (Diospyros kaki-'fuyu'), Pumpkin (Cucurbita pepo), Carrots (Daucus carota subsp. Sativus), wholly Prickly pear (Opuntia ficusindica), were prepared from a culture near Giza Governorate as fresh for both of vegetable and fruit. As for commercial apricot sheets purchased from a local supermarket in Giza as control, with a prepared blank sample for comparison.

\section{2-Methods}

2-1-Preparation of each natural extracts (pulp/puree):

Golden berry, Apricot, Persimmon, and Wholly prickly pear (after removing the thorns), were washed well and squeeze with blender, but carrots, and pumpkin with carrot juicer after washing well. Each extract (golden berry, and wholly prickly pear) was filtered, then were used in juice form, also carrots, and pumpkin were used in juices form, but apricot, persimmon were used in pulp form. The fruit puree was poured in a thin layer almost (3$6 \mathrm{~mm}$ thick) on silicone trays or can be poured into a square, which is later cut into small pieces, or into small circles that are rolled up 
when dry. Pack in plastic bags, label and store in a cool dry place.

\section{2-2-Process and Preparation of Sheets' Sweets Products:}

The producing recipe contains the following ingredients: Juices and Pulp $(500 \mathrm{ml})$, pectin $(200 \mathrm{~g})$, and sugar $(15 \mathrm{~g})$ by using heat-concentrated drying, then put products in air oven at $50^{\circ} \mathrm{C}$ overnight until the target final moisture content almost (12-20\%) has been reached. An aqueous solution of citric was added to the formulation before drying to enhance the pectin-sugar-acid gelation.

\section{3- Main Physical Parameters and} Chemical Composition of Sheets 'Sweets Products:

The physicochemical analyses of samples were analyzed according to standards of AOAC (Association, 2019). The method for determination of moisture content, Total soluble solids, crude fiber, ash, total acidity, total sugars, reducing sugars and non- reducing sugars content.

\section{4- Determination of Ascorbic Acid} (Vit., C):

Vitamin $\mathrm{C}$ as $\mathrm{mg}$ ascorbic acid was determined and estimated per $100 \mathrm{ml}$ fruit juice in the samples using the 2,6dichlorophenol indophenol as described by Ranganna(1977).

\section{5- Determination of Minerals:}

The mineral were determined as following; after the ashes samples were digested according to AOAC, then were determined in the solution acid using Microwave Plasma Atomic Emission Spectroscopy 4210 MPAES, using a blank solution and standard solutions for every element was prepared.

6- Non- enzymatic browning (Color index at $420 \mathrm{~nm}$.):

The increase in absorbance of a sample extract at $440 \mathrm{~nm}$ is taken as a measure of nonenzymatic browning. The color also is measured at $420 \mathrm{~nm}$.Extract 4-5 gm of sample with $100 \mathrm{ml}$ of $60 \%$ alcohol for $12 \mathrm{hr}$. and filter. For sample containing chlorophyll, shake the alcoholic extract with three lots of $50 \mathrm{ml}$ benzene. If the filtrate is not clear, refilled using filter aid. Measure the color at $440 \mathrm{~nm}$ using $60 \%$ aqueous alcohol as blank, according to Ranganna, (1977).

7-Antioxidants Activity (DPPH $\%)$ : 
The free radical scavenging effect of plant extracts was assessed by the discoloration ethanol solution of DPPH radical 0.2 aromatic in ethanol according to (Aromatic et al., 2013).

\section{8-Reconstitution of Sheets'} Sweets Products:

Reconstitution of Sheets' Sweets Products was determined according to the method stated by Von Loesecke (1955) as following: $10 \mathrm{~g}$ the tested dry material samples were placed in $600 \mathrm{ml}$ pyrex beaker. Added 80 to $150 \mathrm{ml}$ distillated water were added, covered with a watch glass, placed on electric heater, as boiled for 5 min., removed from the heater and dumped into a $75 \mathrm{~min}$., Buchner funnel which was covered with a coarsely porous filter paper. Suction was gently applied and drained with careful stirring for one min., or until the drip from the funnel stopped. Samples were removed from the funnel and a weighted calculation was been made to express in terms of "Reconstitution ration".

Reconstitution ratio $=$ the drained weight of the rehydration sample (WR) / the origin weight of the dehydration sample (WD). X 100
9- Sensory evaluations of Sheets, Sweets products:

For the sensory evaluated a simple hedonic scale with a small number of points (from 1 to 10 with 1 - i don`t like it and 10 - i like it very much) was used in order to evaluate the first impression. The aspect, the quality attributes (color, taste, flavor, texture, appearance and overall palatability of the samples of sheet's sweets compared to commercial (control) and blank sample (Apricot) was done. Using suggested was evaluated for their sensory characteristics by ten volunteers from the staff of the Processing Crops, Research Dep., Agric. Res. Center, Giza. Palatability giving numerical scores to each of their attributes from 10 volunteers. The produced was organoleptic ally judged by groups of panel volunteers. The quality was scored on a scale (1 to 10). The following scale was applied to all samples for color, taste, flavor, texture, appearance, and overall palatability as follows: Excellent $=$ (10), Very good $=(8-9)$, Palatable $=(6-7)$, and Unpalatable $=(0-$ $5)$.These proportion were scored on a scale from 1-10 according to Watts et al., (1989). 


\section{0- Statistical analysis:}

The obtained data statistically analyzed by Analysis of Variance method using General Liner Model (GLM) procedure according to Sendecor and Cochran (1997). Means were obtained using Duncan's test at a degree of significance $(\mathrm{P} \leq 0.05)$. Statistical analyses were made using the producer of the SAS software system program (SAS, 1997). SAS (1997). Statistical Analysis System. User's Guide: Statistics, SAS Institute Inc, Gary, Nc., USA.

\section{RESULTS \& DISCUSSION}

Fruit leathers are pectin gels obtained by dehydrating of fruit purees to produce restructured, attractive flexible sheets, which retain shape and are eaten in the form of snack or dessert. Some commercial brands offer thin bars of diverse composition, with or without real fruit solids. These products add variety to a healthy diet and possess dietary fiber, vitamins and minerals while providing a good energy intake. Fruit leathers are prepared from fluid-like formulations placed in trays and dehydrated in hot air dryers. The formulation usually consists of fruit puree added with sucrose or glucose syrup to increase sweetness, solids content, and to reinforce the sugar-acid-high methoxyl pectin gelation. Besides, citric acid may be added to reach the $\mathrm{pH}$ below 3.5 , because of low $\mathrm{pH}$, carboxyl groups of pectin are un-dissociated and participate in hydrogen bonds that support gel structure. Hot air dryers have given the quality indices and nutritional retention in relation to the drying technique utilized, as well being this useful and the best for industry as well health-conscious consumers. Generally, a moisture content of $15-25 \%$ is preferred for fruit leathers; however, it is affected by sugar content, acidy of the fruit, drying process, temperature, and humidity [Ruiz, et al., (2012); Hewavitharana, et al., (2013)]. Furthermore, although low moisture content may prolong shelf life by preventing the fruit leathers from inhibiting microbial growth, the texture of the fruit leathers can be negatively affected due to extensive crispiness of the product, [Perera,(2005); Ciurzy 'nska, et al., (2019)].

The data presented in Table (1), demonstrate that moisture content of samples (wholly prickly pear, carrot, pumpkin) there were no significantly different at $\mathrm{p} \leq 0.05$., 
while samples (golden and persimmon) were $(14.06 \%$, $16.54 \%, 18.53 \%$ ) including control sample had the highest values compared to blank sample $(12.83 \%)$ which was in agreement with data of (Lemuel et al., 2014). However total solids of samples (wholly prickly pear, carrot, pumpkin) there are no significantly different at $\mathrm{p} \leq 0.05$. In general, it noticed that all samples had the highest values compared to blank sample except the control sample which was lower, while total soluble solids was observed that the samples (pumpkin, carrot ,persimmon) including control sample had the highest values (10.0 $0^{\circ}$ Brix, $9.0^{\circ} \mathrm{Brix}$, and $8.5^{\circ} \mathrm{Brix}$ ) respectively., except sample of persimmon was quite similar to control sample. On the other hand, sample of wholly prickly pear was $\left(5.0^{\circ}\right.$ Brix $)$ the lowest one but golden berries was $\left(7.0^{\circ}\right.$ Brix $)$ approximates to blank sample $\left(6.0^{\circ}\right.$ Brix $)$. Dietary fiber has been reported to lower the glycemic indices of food and have been proposed as important for a healthy gut micro-biome (Aziz, et al., 2013). Fibers content, it could be observed that, in pumpkin, carrot, wholly prickly pear sheets samples there were no significantly difference at $p \leq 0.05$, but persimmon sheets $(0.2)$ were the lowest one compared to blank (apricot sheet) sample as well the other samples. As for golden berries sheets were $(0.4 \%)$ as that of control sample. It is evident from previous research conducted that dietary fiber produces a viscous gel-like environment in the small intestine and this slows down gastric emptying, thereby facilitating a gradual release of sugar into the bloodstream. This avoids a glucose spike in the blood, and a reduced hunger sensation and eventually decrease food consumption (French and Read, 1994). The present study the ash content, it noticed that, in general wholly prickly pear sheet $(2.6 \%)$ and blank (apricot sample) sheet had $(2.8 \%)$ were close together as well golden berries $(5.7 \%)$ and carrot sheets had (4.6\%) were fairly close, while the other samples including control sheet sample were the least $(1.8 \%, 1.5 \%$, and $1.3 \%$ ) respectively,. Total acidity (as citric acid) had been observed in blank sample (apricot sheet) and persimmon sheet sample $(10.7 \%$ and $10.5 \%)$ respectively. While the highest and similar values, which mean there are no significantly different at $\mathrm{p} \leq 0.05$., followed by golden berries, and pumpkin sheets samples had the same values $(2.1 \%)$, but carrot sheet $(3.9 \%)$ more than wholly 
prickly pear $(3.4 \%)$ compared to control sheet $(3.1 \%)$. Vitamin C, from those data in general, golden berries sheet sample was the highest value $(53.4 \mathrm{mg} / 100 \mathrm{~g})$ followed by wholly prickly pear and pumpkin sheets samples were $(16.0 \mathrm{mg} / 100 \mathrm{~g}$ and $12.1 \mathrm{mg} 100 \mathrm{~g}$ ) respectively., while the other sheets samples including both of blank and control were very least. The natural sugar present in fruit leather is fructose, with a number of micronutrients plus fiber. Furthermore, better access to information on the amounts of sugar added to processed food is essential for appropriate monitoring of this important energy source (Somerset, 2003). Total sugars of persimmon and wholly prickly pear sheets samples had $(66.95 \%$ and $65.62 \%)$ which were the highest one, followed by golden berries $(42.34 \%)$, blank (apricot) sample (38.85\%) and carrots $(37.39 \%)$, as well the other pumpkin sheets sample including control had value $(31.24 \%$ and $19.90 \%$ ), which were less in their content of total sugars. Reducing sugars, it could be noticed that, wholly prickly pear and persimmon sheets samples had (62.20\% and $61.06 \%$ ), which were the highest one this is the opposite of what was mentioned with total sugars in the same samples, followed by blank (apricot) sample (37.85\%), golden berries $(29.86 \%)$. Also were, the values for these samples were opposite to those of the total sugars as well pumpkin (28.30\%) and, carrots sheet sample (24.11\%), were higher compared to control. As regards non- reducing sugar, it was observed that, all sheets samples were low in their values except carrots (13.28\%), and golden berries $(12.48 \%)$ had the highest one while bank sheet sample $(0.78 \%)$ was the least of them.

The results of the color index at $(420 \mathrm{~nm})$ are presented in Table (2), they manifested that, there are significantly different between all samples compared to control and blank sample at $\mathrm{p} \leq$ 0.05., (Fatih et al., 2015). The results revealed that, total antioxidants activity (DPPH) for the most of sheets samples are no significantly difference at $\mathrm{p} \leq$ 0.05 ., except persimmon sheet was $(50.07 \%)$ had low as that of control sheet (49.66\%), (Huynh Mai Khanh Phuong, et al., 2016). It reported that, significant varietal at $\mathrm{p} \leq 0.05$., differences existed in macro-mineral $(\mathrm{Mg}, \mathrm{Ca}, \mathrm{K}$, and $\mathrm{Na}$ ) composition and extractability of sheets samples varieties (Table 2). It could be mentioned that, 
carrot sheet sample had $(\mathrm{Mg}$; 374.29 ppm, Ca; 1732.10ppm, K; 501.67ppm, and $\mathrm{Na} ; 90.99 \mathrm{ppm})$ was more superior followed by pumpkin sheet sample, while the other samples were moderate in their minerals content, (Rania,et al.,2014). Micronutrients presented in a high numbers of biological processes, as a component of proteins or as essential components of numerous enzymes required for oxidative, amino acids, lipids or carbohydrate metabolism (Mohamed, et al., 2014). The results presented in Table (2) showed significant varietal difference at $p \leq 0.05$., in micro- mineral $(\mathrm{Zn}, \mathrm{Cu}$, and $\mathrm{Fe}$ ) content and extractability. The concentration of iron $(\mathrm{Fe})$ in pumpkin, carrots, and wholly prickly pear sheets samples were $(856.60 \mathrm{ppm}, 835.88 \mathrm{ppm}$, and $663.68 \mathrm{ppm}$ ) respectively were the highest following by golden berries was (573.86ppm).Values of $\mathrm{Cu}$ are significantly difference at $\mathrm{p} \leq 0.05$. in between two groups as following ; the first one was sheets samples group (pumpkin; 1.13ppm and wholly prickly pear;1.09ppm) including the control (1.13ppm) had a high concentrate and the other sheets samples group (golden berries; $0.87 \mathrm{ppm}$, carrots; 0.84 ppm, and persimmon;0.67ppm) including blank sample had a the lowest. It noticed that, golden berries (17.60ppm) sheet sample including blank (11.44ppm) sample had superior in $\mathrm{Zn}$ mineral content.

The reconstitution ratio results in Table (3) represented that, reconstitution ratio of water absorbed by the sample had supposed to decrease in their values by increasing the rehydration (soaking) time per (30min.,). It was observed that, there was a constancy in reconstitution ratio for the sample (persimmon) sheet with increasing of rehydration time (150 min.,).as that of blank (apricot) sheet which recorded ratio (130\% and 180\%) respectively.,. On the other hand, (pumpkin and golden berries) sheets samples recorded the same ratio $(30 \%)$ were the lease one by increasing soaking time, while carrot sheet recorded ratio $(0.0 \%)$ by increasing rehydration time, as well as wholly prickly pear was as that of control which recorded the same ratio $(50 \%)$. It could be explained that, there are significantly difference at $\mathrm{p} \leq$ 0.05 ., of the reconstitution ratio parameters between all sheets samples compared to the control and blank samples (Lemuel, et al., 2014). 
All fruit leathers were then analyzed for their organoleptic characteristics such as (color, flavor, texture, taste, appearance, and overall palatability) during storage period of (3 months). From data in Table (4) these results revealed that, all leather remained unchanged during storage period and have shown a remarkable ranking even after storage period. It was also observed during the study that, all fruit leather had identical color, flavor and wetness, which cannot be compared with one another. However overall mean values represent high score for pumpkin sheet sample followed by blank sample (apricot) and then carrot sheet sample as well golden berries sheet sample respectively. , but wholly prickly pear as that of persimmon which both of them were less overall palatability (good) compared to control. In general, these results indicated that, there were slight significantly difference at $\mathrm{p} \leq 0.05$., in between sheets samples compared to (control and blank) samples while the samples including the blank sample exceed the control. Fruit pulp-based fruit leathers are nutritious and organoleptic acceptable to customers. They contain substantial quantities of dietary fibers, carbohydrates, minerals, vitamins, and antioxidants, which remain constituents of the finished product ( Rozina Naz,2012).

\section{CONCLUSION \& RECONMMEN- DATION}

Fresh fruits and vegetables are known to be excellent sources for energy, minerals, vitamins and bioactive compounds (phenolics, carotenoids) and fibers. The destruction of the original fruit structure by pureeing/squeezes and its restructuring in dehydrated sugar-acid-pectic gels called fruit sheets, which provide attractive, colorful products, on that world, is trend nowadays. The data from this study will be useful to food industry and consumers who are health-conscious. Total antioxidants activity (DPPH) for the most of sheets samples are no significantly different at $\mathrm{p} \leq 0.05$., compared to both of (blank and control samples). The most of sheets samples are involved of both macronutrients and micro- mineral $(\mathrm{Zn}, \mathrm{Cu}$, and $\mathrm{Fe}$ ) minerals content. The reconstitution ratio that there are significantly difference at $\mathrm{p} \leq$ 0.05 ., between all sheets samples. Finally, it could be clearly concluded through this study, that it is technical, available and economic to utilize different vegetables and fruits in producing 
dehydrated sheets products as alternatives to artificial sweets.

\section{REFERENCES}

Association of Official Analytical

Chemists-AOAC (2019):

Official Methods of

Analysis, Washington:

AOAC, $21^{\text {ed. }}$

Aromatic FA; Elmhdwi MF; Aromatic F and Aromatic $O O$ (2013):

Estimation of antioxidant activities of fixed and volatile oils extracted from Aromatic aromatic (clove).

Der Chemica Sinica, 4 (3):120-125.

Aziz Q; Doré J; Emmanuel A; Guarner $F$ and Quigley EJN (2013):

Gut microbiota and gastrointestinal health: Current concepts and future directions. J. Neurogastroenterology 25, 4-15.

Ciurzy 'nska A; Cie'sluk P; Barwi 'nska M; Marczak W; Ordyniak A; Lenart A and Janowicz M (2019):

Eating Habits and
Sustainable
Production in $\begin{array}{r}\text { Food } \\ \text { the }\end{array}$

Development of Innovative "Healthy" Snacks.

Sustainability, 11, 2800.

\section{Ewaidah EH and Hassan BH (1992):}

Prickly pear sheets: a new fruit product. International journal of food science and technology. 27,(3): 353358.

French SJ and Read NW (1994): Effect of guar gum on hunger and satiety after meals of differing fat content: Relationship with gastric emptying. Am. J. Clin. Nutr. 59, 87-91.

Fatih MY; Sultan Y; Hasan V and Mehmet $K$ (2015):

The effects of drying conditions on moisture transfer and quality of pomegranate fruit leather (pestil). J Saudi Societ $y$ Agr Sci.

Hewavitharana AK; Tan ZW; Shimada R; Shaw PN and Flanagan BM (2013):

Between fruit variability of the bioactive compounds, $\beta$-carotene and mangiferin, in mango (Mangifera indica). Nutr. Diet. 70, 158-163. 
Huang $X$ and Hsieh FH (2005):

Physical

properties, sensory attributes, and consumer preference of pear fruit leather. Journal of Food Science, vol. 70, no. 3, pp., 177-186.

Huynh MKP; Nguyen DHH and Nguyen VHH (2016):

Effects of added Pectin amounts and Drying Temperatures on Antioxidants Properties of Mulberry Fruit Leather. Journal of Biotechnology 14(1A): 487-495.

\section{Lemuel M; Xue B and Janette B} (2014):

Fruit leathers: Methods of preparation and effect of different conditions on qualities. Int J Food Sci: 12 pages.

Mohamed RMA; Fageer ASM; Eltayeb MM and Mohamed IA (2014):

Chemical composition, antioxidant capacity, and mineral extractability of Sudanese date palm (Phoenix dactylifera L.) fruits. Food Science and Nutrition, 2(5): 478- 489.
Moyls AL (1981):

Drying of apple puree. Journal of Food Science, vol. 46, pp. 939-942.

\section{Perera CO (2005):}

Selected quality attributes of dried foods. Dry Technol. 23, 717-730.

Ranganna SC (1977):

Manual of analysis of Fruit and Vegetable Products, Tata. McGraw- Hill Publishing Company

Limited.

Rozina N (2012):

Physical properties, sensory attributes and consumer preference of fruit leather. PAK. J. Food SCI., 22(4): 188-190.

Ruiz NAQ; Demarchi SM; Massolo JF; Rodoni LM and Giner SA (2012):

Evaluation of quality during storage of apple leather. LWT J. Food Sci. Technol. 47, 485-492.

\section{Sendecor GW and Cochran WC} (1997):

Statistical Methods; $7^{\text {th }} E d$. Oxford and $j ; \quad$ B.H. Publishing Co. pp. 504. 
Somerset SM (2003):

Refined sugar intake in Australian children. Public Health Nutr. 6, 809-813.
Chapman and Hall Ltd., London.
Vatthanakul S; Jangchud A; Jangchud K; Therdthai $N$ and Wilkinson B (2010):

Gold kiwi fruit leather product development using quality function deployment approach. Food Quality and Preference, vol. 21, no. 3, pp. 339-345.
Watts BM; Ylimaki GL; Jeffery LE and Elias LG (1989):

Basic Sensory Methods for Food Evaluation, International Development Research Center, Ottawa, Canada, 60-63.

\section{Von-Loesecke KW (1955):}

Drying and dehydration of food, Reinhold publishing corporation New York 
Table (1) Chemical Composition for Sheets' Sweets Pieces Products on (dry weight basis).

\begin{tabular}{|c|c|c|c|c|c|c|c|c|c|c|}
\hline $\begin{array}{l}\text { Parameters. } \\
\text { Treatments. }\end{array}$ & $\begin{array}{l}\text { Moisture } \\
\text { Content } \\
\text { (\%) }\end{array}$ & $\begin{array}{l}\text { Total } \\
\text { Solids } \\
\text { (TS) } \\
(\%)\end{array}$ & $\begin{array}{l}\text { Total } \\
\text { Soluble } \\
\text { Solids } \\
\text { (TSS). } \\
\text { ( }{ }^{\circ} \text { Brix) }\end{array}$ & $\begin{array}{l}\text { Fibers. } \\
(\mathrm{g} / \mathbf{1 0 0 g})\end{array}$ & $\begin{array}{l}\text { Ash } \\
(\%) .\end{array}$ & $\begin{array}{l}\text { Total Acidity } \\
\text { (as citric acid.) } \\
\text { (\%) }\end{array}$ & $\begin{array}{l}\text { Vit C/ } \\
(\mathrm{mg} / 100 \mathrm{~g})\end{array}$ & $\begin{array}{l}\text { Total Sugar } \\
\text { Sugars } \\
(\%)\end{array}$ & $\begin{array}{l}\text { Reducing } \\
\text { Sugars } \\
(\%)\end{array}$ & \begin{tabular}{l}
\multicolumn{1}{c}{ Non- } \\
reducing \\
Sugars \\
$(\%)$
\end{tabular} \\
\hline$* *$ Control. & $18.53^{\mathrm{a}}$ & $81.47^{\mathrm{b}}$ & $8.5^{\mathrm{a}}$ & $0.4^{\mathrm{bc}}$ & $1.3^{\mathrm{d}}$ & $3.1^{\mathrm{b}}$ & $8.8^{\mathrm{c}}$ & $19.90^{\mathrm{c}}$ & $17.69^{c}$ & $2.21^{\mathrm{d}}$ \\
\hline$* * *$ Blank (Apricot). & $12.83^{\mathrm{e}}$ & $87.17^{\mathrm{a}}$ & $6.0^{\mathrm{b}}$ & $0.5^{\mathrm{b}}$ & $2.8^{\mathrm{c}}$ & $10.7^{\mathrm{a}}$ & $9.5^{\mathrm{c}}$ & $38.63^{\mathrm{b}}$ & $37.85^{\mathrm{b}}$ & $0.78^{\mathrm{e}}$ \\
\hline Golden berries. & $14.06^{\mathrm{c}}$ & $85.94^{\mathrm{ab}}$ & $7.0^{\mathrm{b}}$ & $0.4^{\mathrm{bc}}$ & $5.7^{\mathrm{a}}$ & $2.1^{\mathrm{c}}$ & $53.4^{\mathrm{a}}$ & $42.34^{\mathrm{b}}$ & $29.86^{\mathrm{b}}$ & $12.48^{\mathrm{a}}$ \\
\hline Persimmon. & $16.54^{\mathrm{b}}$ & $83.46^{\mathrm{ab}}$ & $8.5^{\mathrm{a}}$ & $0.2^{\mathrm{c}}$ & $1.5^{\mathrm{d}}$ & $10.5^{\mathrm{a}}$ & $7.7^{\mathrm{d}}$ & $66.95^{\mathrm{a}}$ & $61.06^{\mathrm{a}}$ & $5.89^{b}$ \\
\hline Wholly Prickly Pear. & $13.83^{\mathrm{d}}$ & $86.17^{\mathrm{a}}$ & $5.0^{\mathrm{b}}$ & $0.7^{\mathrm{ab}}$ & $2.6^{\mathrm{c}}$ & $2.4^{\mathrm{c}}$ & $16.0^{\mathrm{b}}$ & $65.62^{\mathrm{a}}$ & $62.20^{\mathrm{a}}$ & $3.42^{\mathrm{c}}$ \\
\hline Pumpkin & $13.36^{\mathrm{d}}$ & $86.64^{\mathrm{a}}$ & $10.0^{\mathrm{a}}$ & $0.9^{\mathrm{a}}$ & $1.8^{\mathrm{d}}$ & $2.1^{\mathrm{c}}$ & $12.1^{\mathrm{b}}$ & $31.24^{\mathrm{b}}$ & $28.30^{\mathrm{b}}$ & $2.94^{d}$ \\
\hline Carrots. & $13.82^{\mathrm{d}}$ & $86.18^{\mathrm{a}}$ & $9.0^{\mathrm{a}}$ & $0.8^{\mathrm{a}}$ & $4.6^{\mathrm{b}}$ & $3.9^{\mathrm{b}}$ & $5.1^{\mathrm{d}}$ & $37.39^{\mathrm{b}}$ & $24.11^{\mathrm{b}}$ & $13.28^{\mathrm{a}}$ \\
\hline
\end{tabular}

*Means followed by different letters in the same column are significantly difference at $p \leq 0.05$.

**Control (Commercial Sheets). $\quad$ *** Blank (Apricot Sheets) Sample was done. 
Table (2) Colors Index at (420nm)/ Total Antioxidants Activity/ Main Minerals in Sheets' Sweets Pieces Products on (dry weight basis).

\begin{tabular}{|c|c|c|c|c|c|c|c|c|c|}
\hline \multirow{2}{*}{$\begin{array}{c}\text { Parameters. } \\
\text { Samples. }\end{array}$} & \multirow{2}{*}{$\begin{array}{l}\text { Colors } \\
\text { Index at } \\
(420 \mathrm{~nm}) .\end{array}$} & \multirow{2}{*}{$\begin{array}{l}\text { Anti-oxidative } \\
\text { Activity. } \\
\text { (DPPH \%). }\end{array}$} & \multicolumn{7}{|c|}{ Main Minerals (mg/kg). } \\
\hline & & & $\mathrm{Zn}$ & $\mathrm{Cu}$ & $\mathrm{Fe}$ & $\mathrm{Mg}$ & $\mathrm{Ca}$ & K & $\mathrm{Na}$ \\
\hline$* *$ Control. & $0.4493^{c}$ & $49.66^{\mathrm{b}}$ & $6.77^{\mathrm{c}}$ & $1.13^{\mathrm{a}}$ & $360.54^{\mathrm{d}}$ & $86.83^{\mathrm{d}}$ & $1317.90^{\mathrm{f}}$ & $534.20^{\mathrm{a}}$ & $9.75^{\mathrm{g}}$ \\
\hline ***Blank (Apricot). & $0.8031^{\mathrm{a}}$ & $51.22^{\mathrm{a}}$ & $11.44^{\mathrm{b}}$ & $0.75^{\mathrm{b}}$ & $205.87^{\mathrm{e}}$ & $194.76^{\mathrm{c}}$ & $1897.60^{\mathrm{b}}$ & $586.03^{\mathrm{a}}$ & $21.39^{\mathrm{f}}$ \\
\hline Golden berries. & $1.0664^{\mathrm{a}}$ & $51.56^{\mathrm{a}}$ & $17.60^{\mathrm{a}}$ & $0.87^{\mathrm{b}}$ & $573.86^{\mathrm{c}}$ & $398.44^{\mathrm{a}}$ & $1463.10^{\mathrm{e}}$ & $510.85^{\mathrm{ab}}$ & $44.07^{\mathrm{e}}$ \\
\hline Persimmon. & $0.1963^{\mathrm{e}}$ & $50.07^{\mathrm{b}}$ & $2.37^{\mathrm{d}}$ & $0.67^{\mathrm{b}}$ & $368.78^{\mathrm{d}}$ & $210.90^{\mathrm{b}}$ & $1126.60^{\mathrm{g}}$ & $441.35^{b}$ & $49.10^{\mathrm{d}}$ \\
\hline Wholly Prickly Pear. & $0.2779^{\mathrm{d}}$ & $51.07^{\mathrm{a}}$ & $6.55^{\mathrm{c}}$ & $1.09^{\mathrm{a}}$ & $835.88^{\mathrm{a}}$ & $275.80^{\mathrm{b}}$ & $7139.60^{\mathrm{a}}$ & $480.41^{\mathrm{ab}}$ & $63.62^{\mathrm{c}}$ \\
\hline Pumpkin. & $0.5642^{\mathrm{b}}$ & $51.11^{\mathrm{a}}$ & $6.68^{c}$ & $1.13^{\mathrm{a}}$ & $857.60^{\mathrm{a}}$ & $378.55^{\mathrm{a}}$ & $1664.20^{\mathrm{d}}$ & $442.95^{\mathrm{b}}$ & $77.02^{\mathrm{b}}$ \\
\hline Carrots. & $0.2556^{\mathrm{d}}$ & $51.34^{\mathrm{a}}$ & $2.66^{\mathrm{d}}$ & $0.84^{\mathrm{b}}$ & $663.68^{\mathrm{b}}$ & $374.29^{\mathrm{a}}$ & $1732.10^{c}$ & $501.67^{\mathrm{ab}}$ & $90.99^{\mathrm{a}}$ \\
\hline
\end{tabular}

*Means followed by different letters in the same column are significantly difference at $p \leq 0.05$.

**Control (Commercial Sheets). $\quad * * *$ Blank (Apricot Sheets) Sample was done. 
Table (3) Reconstitution Ratio for Sheets' Sweets Pieces Products at Ambient Temp., $\left( \pm 25^{\circ} \mathrm{C}\right)$.

\begin{tabular}{|c|c|c|c|c|c|}
\hline $\begin{array}{l}\text { Rehyd., Sample / (Time } \\
\text { /30min). } \\
\text { Treatments. }\end{array}$ & $30 \mathrm{~min}$ & $60 \mathrm{~min}$ & $90 \mathrm{~min}$ & $120 \mathrm{~min}$ & $150 \mathrm{~min}$ \\
\hline$* *$ Control. & $110^{\mathrm{a}}$ & $90^{\text {ab }}$ & $8^{\text {ab }}$ & $60^{b}$ & $50^{b}$ \\
\hline$* * *$ Blank (Apricot). & $180^{c}$ & $200^{\mathrm{a}}$ & $200^{\mathrm{a}}$ & $190^{b}$ & $180^{c}$ \\
\hline Golden berry. & $130^{\mathrm{a}}$ & $110^{\mathrm{ab}}$ & $90^{\mathrm{ab}}$ & $50^{b}$ & $30^{b}$ \\
\hline Persimmon. & $120^{d}$ & $130^{c}$ & $150^{a}$ & $140^{b}$ & $130^{c}$ \\
\hline Wholly Prickly Pear. & $140^{\mathrm{a}}$ & $110^{\mathrm{ab}}$ & $100^{\mathrm{ab}}$ & $80^{b}$ & $50^{b}$ \\
\hline Pumpkin. & $160^{\mathrm{a}}$ & $150^{\mathrm{a}}$ & $90^{b}$ & $50^{\mathrm{bc}}$ & $30^{c}$ \\
\hline Carrots. & $120^{\mathrm{a}}$ & $100^{a b}$ & $60^{b}$ & $30^{c}$ & $0.0^{\mathrm{d}}$ \\
\hline
\end{tabular}

${ }^{*}$ Means followed by different letters in the same column are significantly difference at $p \leq 0.05$.

***ontrol (Commercial Sheets). $\quad * * *$ Blank (Apricot Sheets) Sample was done. 
Table (4) Sensory Evaluation of Sheet's Sweets Pieces Products after Being Storage at Ambient Temp., (25 \pm 2 ) for 3 Months.

\begin{tabular}{|l|c|c|c|c|c|c|c|}
\hline \multicolumn{1}{|c|}{ Samples. } & $\begin{array}{c}\text { Appearance } \\
(10)\end{array}$ & $\begin{array}{c}\text { Color } \\
(10)\end{array}$ & $\begin{array}{c}\text { Flavor } \\
(10)\end{array}$ & $\begin{array}{c}\text { Texture } \\
(10)\end{array}$ & $\begin{array}{c}\text { Taste } \\
(10)\end{array}$ & $\begin{array}{c}\text { Overall Score } \\
(50)\end{array}$ & $\begin{array}{c}\text { Overall } \\
\text { Palatability }\end{array}$ \\
\hline$* *$ Control. & $7.1^{\mathrm{b}}$ & $6.4^{\mathrm{b}}$ & $7.0^{\mathrm{b}}$ & $6.7^{\mathrm{b}}$ & $6.9^{\mathrm{b}}$ & $34.1^{\mathrm{b}}$ & $\mathrm{G}$ \\
\hline$* * *$ Blank (Apricot). & $7.7^{\mathrm{ab}}$ & $7.6^{\mathrm{ab}}$ & $7.7^{\mathrm{a}}$ & $8.0^{\mathrm{a}}$ & $7.6^{\mathrm{ab}}$ & $38.6^{\mathrm{ab}}$ & $\mathrm{V}$ \\
\hline Golden berry. & $7.3^{\mathrm{b}}$ & $6.8^{\mathrm{b}}$ & $7.5^{\mathrm{b}}$ & $7.6^{\mathrm{b}}$ & $7.7^{\mathrm{ab}}$ & $36.9^{\mathrm{ab}}$ & $\mathrm{V}$ \\
\hline Persimmon. & $6.9^{\mathrm{b}}$ & $6.3^{\mathrm{b}}$ & $7.1^{\mathrm{b}}$ & $7.6^{\mathrm{b}}$ & $7.2^{\mathrm{b}}$ & $35.1^{\mathrm{b}}$ & $\mathrm{G}$ \\
\hline Wholly Prickly Pear & $7.1^{\mathrm{b}}$ & $6.3^{\mathrm{b}}$ & $7.3^{\mathrm{b}}$ & $7.4^{\mathrm{b}}$ & $7.3^{\mathrm{b}}$ & $35.4^{\mathrm{b}}$ & $\mathrm{G}$ \\
\hline Pumpkin. & $8.8^{\mathrm{a}}$ & $8.7^{\mathrm{a}}$ & $8.2^{\mathrm{a}}$ & $8.7^{\mathrm{a}}$ & $8.4^{\mathrm{a}}$ & $42.8^{\mathrm{a}}$ & $\mathrm{V}$ \\
\hline Carrots. & $7.8^{\mathrm{ab}}$ & $6.4^{\mathrm{b}}$ & $7.9^{\mathrm{a}}$ & $7.8^{\mathrm{ab}}$ & $7.9^{\mathrm{a}}$ & $37.8^{\mathrm{ab}}$ & $\mathrm{V}$ \\
\hline
\end{tabular}

*Means followed by different letters in the same column are significantly different at $p \leq 0.05$.

**Control (Commercial Sheets). $\quad * * *$ Blank (Apricot Sheets) Sample was done 


\section{الاستفادة من بعض لب الفاكهة والخضروات فى ثصنيع منتجات (قطع حلوى اللفائف) \\ نسرين محمد السعيد علي \\ معهد بحوث تكنولوجيا الاغذية ـ مركز البحوث الزراعية}

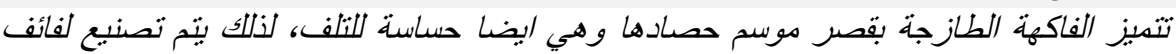

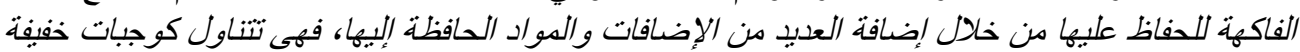

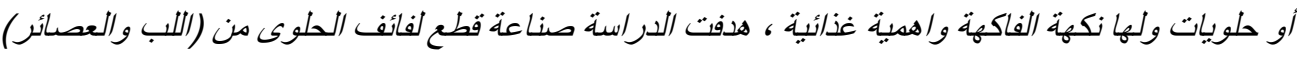

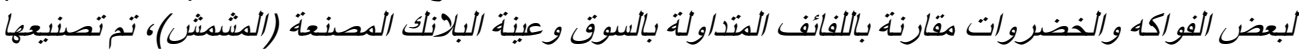

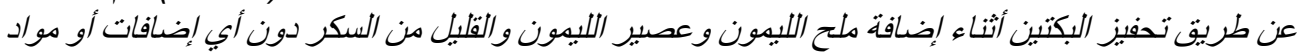

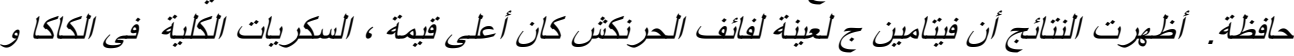

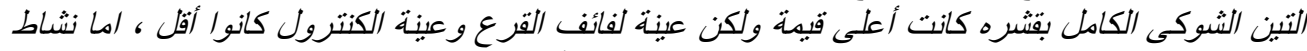

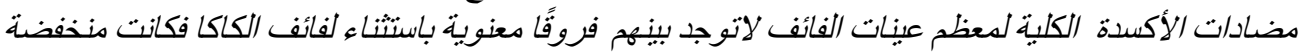

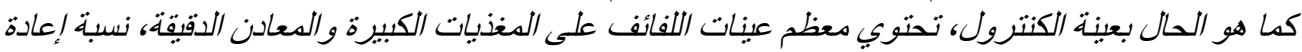

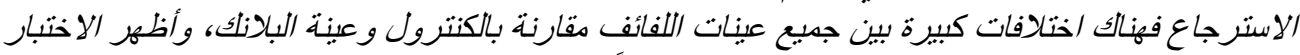

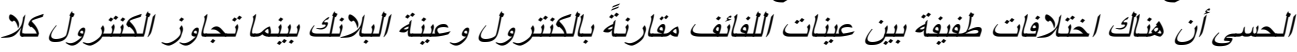

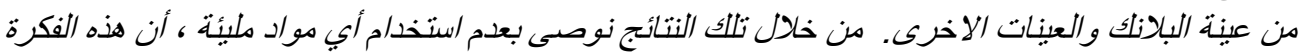

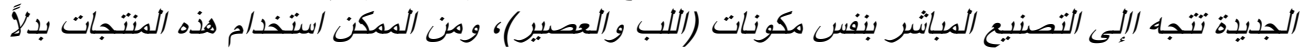

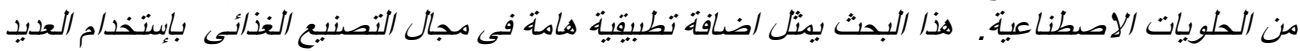

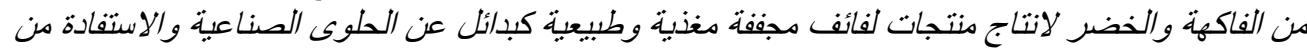

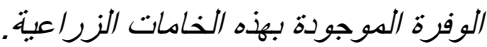

الكلمات المفتاحية: لب وعصبر (الفاكهة والخضروات)- قطع حلوى اللفائف 